Hobson, K. A. 2021. Ontario's decision for the province-wide cull of Double-crested Cormorants. Avian Conservation and Ecology 16(1):24. https:// doi.org/10.5751/ACE-01949-160124

Copyright (C) 2021 by the author(s). Published here under license by the Resilience Alliance.

Editorial

\title{
Ontario's decision for the province-wide cull of Double-crested Cormorants
}

\author{
Keith A. Hobson
}

${ }^{1}$ Department of Biology, University of Western Ontario, London, Ontario, Canada

\section{La décision de l'Ontario quant à l'abattage des Cormorans à aigrettes à la grandeur de la province}

Key Words: cormorants; diet; management; persecution; Laurentian Great Lakes; Ontario

\section{INTRODUCTION}

On the eve of the 100th anniversary of the convention between the United States and Canada to protect migratory birds in North America, Linda Wires published an invited editorial in this journal titled "Migratory bird protection, a crack in the armor: the case of the Double-crested Cormorant" (Wires 2015). In Canada the Migratory Birds Convention Act, 1994 (MBCA) was passed in 1917, while in the United States the Migratory Bird Treaty Act (MBTA) was passed in 1918. These acts resulted in the implementation of the convention in each country and provided protection under the law to migratory birds, their nests, and eggs. This protection represents a milestone internationally in bird conservation efforts. As her title suggested, the Doublecrested Cormorant (Phalacrocorax auritus) was one species that received no such national protection as a result of this treaty, a decision that reflected hundreds of years of persecution. An interesting aspect of Wires editorial was that she contrasted cormorant control in Canada with the United States and considered Canada's record favorably compared to that of our southern neighbor. That is not to say that Canada has not engaged in considerable persecution of this species but that our measures have hitherto been more targeted and considered compared with the depredation orders of the United States that have resulted in the greatest culling of any native North American species. Regardless, the establishment of depredation orders in the United States and the culling of birds in Canada has led to well over half a million Double-crested Cormorants killed, by Wires (2014) account. Unfortunately, the tide has turned and recent events in the province of Ontario stand to dramatically change the standing of Canada's record on this front.

In her book The Double-crested Cormorant: Plight of a Feathered Pariah, Wires concluded a monumental accounting of the persecution of the Double-crested Cormorants in North America through 2012 (Wires 2014). To that point, Canada's response to cormorant "control" reflected provincial government actions primarily of Alberta, Ontario, and Quebec. That history would not absolve Manitoba that saw massive illegal cormorant killings on Lake Winnipegosis, for example, but did point to key provincial actions that resulted in the destruction of hundreds of thousands of birds, nests, and eggs. Management to benefit fisheries interests,

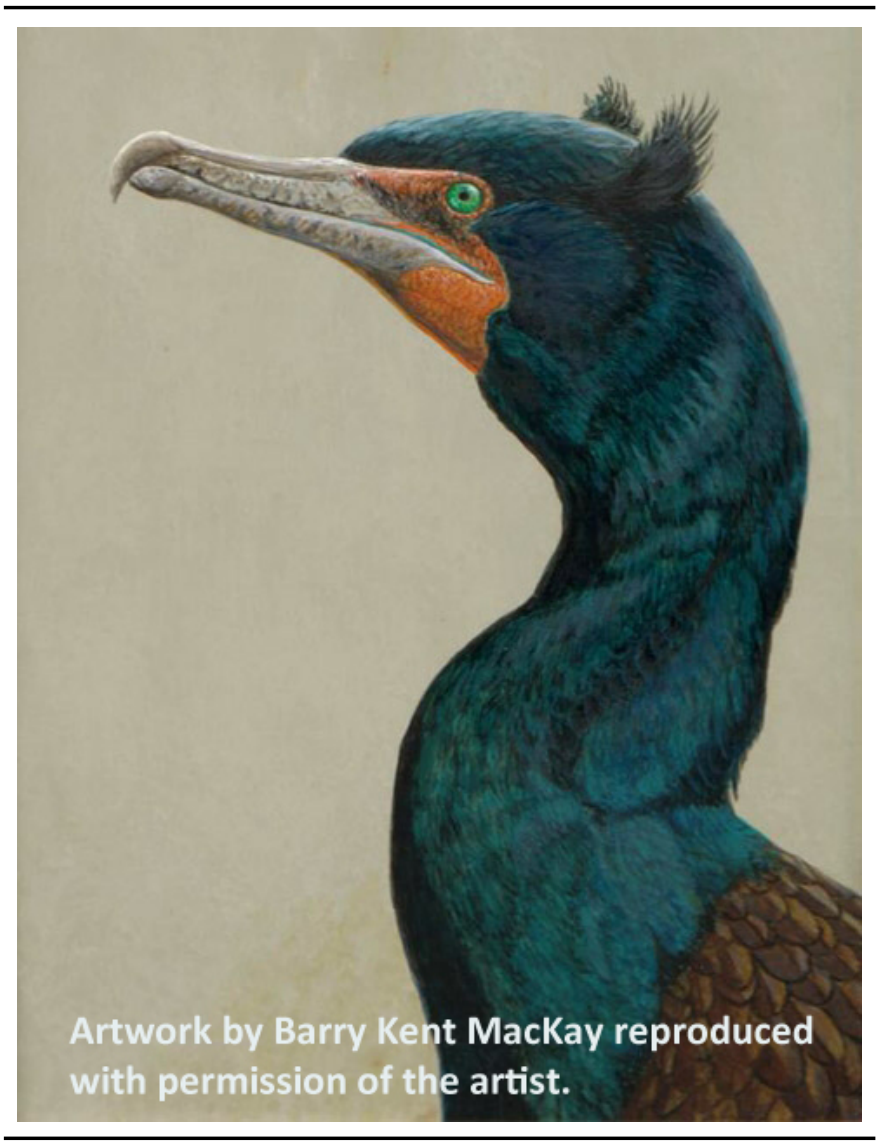

e.g., to recover historical fish communities and/or increase allocations of fisheries to humans, had occurred only in Alberta and Quebec, which had undertaken shooting and egg oiling programs at colonies in just two areas for this purpose, Lac La 
Biche region, Alberta and Lac St. Pierre, Quebec. As documented by Wires (2014) in Ontario, provincial agencies had managed cormorants because of concerns about negative ecological impacts to specific habitats or other species. Large-scale shooting and egg-oiling programs were pursued at two locations, Presqu'ile Provincial Park, and Middle Island, Point Pelee National Park. Conversely, at Tommy Thompson Park, home of the largest colony of Double-crested Cormorants in eastern North America, only nonlethal efforts had been employed. In addition, management at Presqu'ile Provincial Park shifted to nonlethal and deterrent techniques in 2007. Under Ontario's cormorant management policy, management to benefit fisheries was not undertaken; however, the Ontario Ministry of Natural Resources conducted an experimental egg-oiling program for several years in Lake Huron to determine if cormorants affected coastal fish abundance.

Despite a general history of localized management actions that allowed cormorants to be considered to at least some degree as part of our natural avian heritage, the Ontario government recently placed the Double-crested Cormorant on the "game list." That action, the result overwhelmingly of lobbying by the Ontario Federation of Anglers and Hunters (OFAH) of the new Conservative government of Doug Ford, has fundamentally changed the entire approach to how we "live with" this species in Ontario. On 31 July 2020 the Ontario Ministry of Natural Resources and Forestry (MNRF) announced a province-wide fall season for cormorants from 15 September to 31 December. The daily bag limit is 15 birds under the authority of a small game licence (see the MNRF's decision notice for full details, at https:// ero.ontario.ca/notice/013-4124).That highly questionable action derives clearly from the attitude that cormorants are competing with anglers for sports fish as well as annoying those promoting nondisturbance of lakeshore vegetation. However, the scientific evidence is clearly against this notion, which seems deeply based in human psychology that every fish taken by a cormorant is one less to be taken by an angler or to be taken by a fish sought after by an angler, or that somehow, cormorants represent a new threat to island vegetation. The OFAH and others have much explaining to do.

\section{THE OFAH LOBBY}

Much has been written about the history of human-cormorant conflict (Siegel-Causey 1997, Wires 2014, 2015) and obviously this is an issue that will not disappear any time soon (or at least while cormorants persist in their native range). Suffice it to say that the Double-crested Cormorant is a species that has increased tremendously in numbers since early persecution, the end of widespread DDT use, and the massive changes in fish community structure favoring smaller forage fish species as the result of several factors not the least of which is overfishing of top predatory species. Some see this change in population as a "recovery" and others see it as an "invasion." Cormorants eat fish and have always been seen as competitors with sport and commercial fisheries. They can be particularly problematic at catfish farms on wintering grounds in the southern United States but notably, that industry has collapsed because of an inability to compete with Asian markets and not because of cormorants. Cormorants often also nest in large colonies on islands or lakeshores and their presence typically impacts local vegetation. Many see the bird also as being ugly and generally useless. It is no surprise then that the Ontario Federation of Anglers and Hunters have been active in lobbying the provincial government of Ontario to dramatically reduce cormorant numbers. OFAH represents over 100,000 "members, subscribers and supporters."

Although the province of Ontario now allows hunting of cormorants province wide from 15 September to 31 December, OFAH advocated a split spring (March to May) and fall hunt to have more maximal impact (OFAH file 413C/794). That may have merit if one was interested in removing birds before they were allowed to breed but a clear concern by OFAH was the public image of hunters and the need to separate killing of cormorants from those months when the general public were also enjoying the Great Lakes. Indeed much of their website (https://www.ofah. org/issues/cormorants/) contains advice to hunters to assume their "ambassador role" in helping the province to "eradicate this pest":

Government Opens Fall Hunting Season for DoubleCrested Cormorants

Populations of double-crested cormorants are increasing in number and distribution across Ontario's shorelines. Where cormorant numbers are high, they can negatively affect terrestrial habitats by chemical and physicalmeans through corrosive acidic guano, and stripping/breaking tree branches. In some cases, cormorant colonies have destroyed entire island ecosystems. Many people are also concerned about potential impacts on fish populations and angling opportunities.

The OFAH is pleased to see that the government is finally recognizing the problems caused by overabundant cormorants and are taking action to control overabundant cormorant populations to help protect Ontario's ecosystems. It is encouraging to see that the $M N R F$ has made adjustments to the original proposal in response to concerns expressed by the OFAH and others. Provincial government action on cormorants has been a long time coming for many OFAH members, and reinforces the need for persistence and determination when there is a conservation concern that threatens our fish and wildlife.

Also, from Galea (2020),

Ontario's new cormorant hunt is welcome news to anglers, hunters, and recreational boaters, as well as shoreline property owners. But for the hunt to have any real impact on mitigating the ecological mess caused by high concentrations of these fish-devouring birds, there needs to be buy-in from hunters.

So why should you hunt a bird that's not exactly known for its edibility?

The obvious answer can be seen when you examine the damage done to the islands, shorelines, water quality, and fisheries where cormorants congregate. The less obvious answer lies in the historic nature of this decision. The province has essentially called upon its hunters to participate in what amounts to a vast ecological 
stewardship program, meant to keep burgeoning cormorant numbers and the accompanying destruction in check.

At the time of this writing, it is not clear how many OFAH members agree with this hunt, how many are actively participating, and indeed how many cormorants have been shot as part of the fall 2020 hunt and how many will be killed during the upcoming fall hunt of 2021. However, the liberal bag limit of 15 birds per day, even if it can be enforced, allows for considerable impact.

\section{THE SCIENTIFIC EVIDENCE}

It is intriguing to read of the OFAH perception that cormorants are "destroying natural ecosystems- and their view of the "ecological mess caused by high concentrations of these fishdevouring birds." This is particularly interesting when one examines the human history and mismanagement of the Great Lakes in general (see below). Rather, it is obvious to many that Double-crested Cormorants are a scapegoat for the catastrophic and long-term perturbation of these lakes. In local cases where cormorant control is deemed necessary (and supported by scientific evidence), it should be carried out by skilled professionals and not by the general public. Even so, such control measures need to be continually justified within the spirit of adaptive resource management (see below).

As for conflicts with anglers and commercial fisheries, in stark contrast to opinion or a list of anecdotal accounts, scientists have studied diets of Double-crested Cormorants for many decades in various areas of North America and certainly on the Great Lakes of Ontario. Those studies have been based on chick regurgitations at colonies, pellets, and on stomach contents of shot birds. Overwhelmingly, these studies have shown that cormorants pose no threat to sport or commercial fisheries (Hobson et al. 1989, Trapp et al. 1997, Somers et al. 2003, Reed et al. 2007). In the Great Lakes basin, the Double-crested Cormorant has shown remarkable ability to switch prey sources in response to fish composition change. Notably, in eastern Lake Ontario Johnson et al. (2010) documented the swift response of cormorants to the invasive round goby (Neogobius melanostomus), which dominated its diet. A management program for the Upper Niagara River, initiated in 2004, based on stomach contents of 1119 cormorants nesting at two sites in the Upper Niagara River, showed that round goby constituted up to $85 \%$ of the biomass in cormorant diet during the breeding season (Coleman et al. 2012). Later, a similar response was noted in the St. Lawrence River section of the Great Lakes Basin where Johnson et al. (2002, 2015) documented a switch in diet predominantly to round goby from invasive alewife (Alosa pseudoharengus). King et al. (2017) using a variety of investigative techniques including stable isotope assays and essential fatty acid quantification determined that the diet of cormorants in Lake Ontario and Lake Erie consisted almost exclusively of alewife and round goby.

There is simply no current scientific evidence that cormorants breeding in Ontario should be persecuted as a result of competition with human consumers. In fact, the evidence is in the other direction, that cormorants are predominantly taking considerable numbers of invasive damaging fish, especially round goby (Coleman et al. 2012). Their take of invasive alewife should also be considered positively but of course some have argued that this puts them in competition with introduced salmonids, which now constitute an artificial but lucrative sport fishery. Again, there is no scientific evidence that this is the case but it is interesting to reflect on any management that would favor the maintenance of an introduced non-native sport fish over that of a native piscivorous bird.

Other rationale for a province-wide cull of cormorants in Ontario relates to their destruction of forests on islands and lakeshores due to their nesting habits and input of guano. There can be no doubt that cormorants are guilty as charged but this disturbance regime is natural, overwhelmingly local in scale, and simply cannot justify large-scale culling. Wires (2014) puts into perspective this issue from both a scientific and ethical perspective. The oft presented argument that Middle Island in Lake Erie and other nesting sites represent endangered Carolinean forest is rather absurd because the plant species involved are abundant in the bulk of their range south of the Canadian border. Cormorants, like humans, indeed destroy vegetation where they nest but this is obviously a natural process shared by several colonial species and one that has existed for millennia and is renewable. Moreover, destruction by cormorants is incredibly insignificant compared to the massive loss of Carolinean forest by human forces of forestry, agriculture, and more recently massive urban expansion in southern Ontario. Proponents of cormorant killing in cottage country drive through millions of hectares of destroyed Carolinean forest by humans but pay no attention until they reach their coveted shorelines.

As for "fouling local waters," cormorants are an integral part of nitrogen and phosphorus nutrient flux in these freshwater aquatic systems. That is, cormorants, unlike humans, introduce only waste related to fish consumption from the very lakes in question, and the argument becomes laughable in comparison to the magnitude of human-related fouling of the Great Lakes as discussed briefly below.

\section{THE LAURENTIAN GREAT LAKES: A HISTORY OF ENVIRONMENTAL CHANGE AND MISMANAGEMENT}

The Great Lakes of southern Ontario include an enormous volume of freshwater ( $20 \%$ of the Earth's surface freshwater; Magnusson et al. 1997). Unquestionably, this system is one of the most impressive in terms of native biodiversity and productivity. Thousands of plant and animal species occur in the Great Lakes Basin, including over 170 fish species (Hubbs and Lagler 1958). However, also unquestionably, this system is a textbook example of ecological change on a massive scale and one that now faces the additional burden of climate change (McKenna 2019). This brief editorial in no way can adequately summarize this situation and the interested reader is referred at first to the review by McKenna (2019) upon which I have relied (Table 1). Instead, it is worth providing this backdrop because cormorant control here and elsewhere is usually justified as a means of rescuing commercial and sport fisheries and restoring ecological balance. Clearly, a natural ecological system no longer exists in the Great Lakes because of the massive changes that have resulted from overfishing, habitat alteration, and invasive species, both 
Table 1. Summary of ecological disturbances identified for the Laurentian Great Lakes. Based on the review by McKenna (2019). Several factors contribute and interact and the history of individual lakes can differ. The purpose here is to indicate that numerous factors have contributed massively to the profound ecological changes in the Laurentian Great Lakes system.

\begin{tabular}{|c|c|c|}
\hline Disturbance & Description & Key reference \\
\hline Overfishing & $\begin{array}{l}\text { Collapse of the cisco (Coregonus artedi) fishery by } 1960 \mathrm{~s} . \\
\text { Parallel declines in lake whitefish (Coregonus clupeafrormis) and } \\
\text { lake trout (Salvelinus namaycush). } \\
\text { Atlantic salmon (Salmo salar) extirpation. }\end{array}$ & $\begin{array}{l}\text { Van Oosten (1930) } \\
\text { Smith (1964) } \\
\text { Christie (1974) but see Elrod et al. (1995) }\end{array}$ \\
\hline Habitat alteration & $\begin{array}{l}\text { Dams for hydropower, flood control, and navigation. } \\
\text { Intensive land use by agriculture, timber harvest, urbanization. } \\
\text { Pollution. } \\
\text { Eutrophication. } \\
\text { Extirpation of American eel (Anguilla rostrata) by } 2000 . \\
\text { Severe declines in aquatic emergent insects. }\end{array}$ & $\begin{array}{l}\text { McLaughlin et al. (2013) } \\
\text { Poff et al. (1997) } \\
\text { Davies-Colley and Smith (2001) } \\
\text { Fields (2005) } \\
\text { Christie (1974) } \\
\text { Rucinski et al. (2014) } \\
\text { Shepard (2015) }\end{array}$ \\
\hline Invasive species & $\begin{array}{l}\text { Sea lamprey (Petromyzon marinus) } \\
\text { Brown trout (Salmo trutta) } \\
\text { Rainbow trout (Oncorhynchus mykiss) } \\
\text { Alewife (Alosa pseudoharengus) } \\
\text { Pacific salmon (esp. Chinook } \text {. tshawytscha, coho O. coho) } \\
\text { Round goby (Neogobius melanostomus) } \\
\text { Common carp (Cyprinus carpio) } \\
\text { Eurasian milfoil (Myriophyllum spicatum), Hydrilla (Hydrilla } \\
\text { verticillata), and water chestnut (Trapa natans), rock snot } \\
\text { (Didymosphenia geminate), } \\
\text { Rusty crayfish (Orconectes rusticus) } \\
\text { Dreissenid mussels (Dreissena polymorpha, D. bugensis) } \\
\text { Planktonic crustaceans (Bythotrephes longimanus, Cercopagis } \\
\text { pengoi) } \\
\text { Pathogens (viral haemorrhagic septicaemia) }\end{array}$ & $\begin{array}{l}\text { Elrod et al. (1995) } \\
\text { Eshenroder (2014) } \\
\text { Hansen et al. (2016) } \\
\text { Weidel et al. (2017) } \\
\text { Dermott (2001) } \\
\text { Cohen (2010) } \\
\text { Miano (2015) } \\
\text { Nico et al. (2021) }\end{array}$ \\
\hline Climate change & $\begin{array}{l}\text { Water temperature increase severely affects all poikilothermic } \\
\text { organisms. } \\
\text { Increased storm events. } \\
\text { Low flow events and mis-timing of warm water and migratory } \\
\text { movements }\end{array}$ & Stewart et al. (2016) \\
\hline
\end{tabular}

intentional and unintentional. The role of the Double-crested Cormorant as a native piscivore in this system needs to be evaluated in light of current fish composition and productivity and how this has changed and will change in the future.

The original Great Lakes aquatic foodweb was dominated by lake trout (Salvelinus namaycush) as a top predator with cisco (Coregonus artedi) and lake whitefish (C. clupeaformis) as primary forage fish. Migratory Atlantic salmon (Salmo salar) was a major migratory top predator and American eel (Anguilla rostrata) and brook trout (Salvelinus fontinalis) common top predators in streams and tributaries. Although several factors were undoubtedly involved, the massive overfishing of cisco resulted in the collapse of that fishery throughout the region by the 1960s. In parallel, declines in lake whitefish and lake trout populations occurred. The Atlantic salmon was extirpated from Lake Ontario by the early 1900s. Such changes would have been expected to dramatically change the dynamics of fish populations in the Great Lakes but the myriad of invasive species introductions that followed added an interesting layer of complexity due to subsequent changes in predation pressures on and competition with native species.

The list of known invasive species to the Great Lakes is impressive. Brown trout (Salmo trutta) were introduced to tributaries in the late 1800 s and contributed to the decline of the native brook trout.
Rainbow trout (Oncorhynchus mykiss) were introduced in New York in 1874 and occupied stream habitat formerly used by Atlantic salmon. Sea lamprey (Petromyzon marinus) infiltrated Lake Erie and other Great lakes following construction of the Welland Canal and devastated lake trout populations and have led to extensive control measures to try and restore populations. The planktivorous alewife became invasive in the mid 1900s following eutrophication, nutrient pollution, and low piscivore abundance. While alewife became an important forage fish, as an efficient planktivore, it competed strongly with native (coreogonid) planktivores. Alewife also contain high levels of thiamine that are poorly tolerated by native piscivores such as Atlantic salmon. In an effort to control alewife populations, Chinook salmon (Oncorhynchus tshawytscha), coho salmon $(O$. coho), and steelhead (O. mykiss) were introduced initially in Lake Ontario and Lake Michigan thereby creating a multimillion dollar fishery. Currently, it is unclear how introduced alewife and Pacific salmon are interfering with recovery of native fish species.

Dreissenid mussels from the Black Sea introduced through ship ballast have cause substantial ecological change to the Great Lakes because, historically, no significant benthic filter feeder was present. Massive beds of invasive mussels now have shifted much of the pelagic primary production to the benthos. Quickly, the benthic amphipod (Diporea spp.), which was an important prey item for native fish, declined. Similarly, the invasive round goby 
Table 2. From Smith et al. (2015). Ranks of the eight highest-rated environmental stressors by lake based on expert elicitation in the Laurentian Great Lakes. Numbers in parentheses indicate number of expert survey respondents for each lake.

\begin{tabular}{|c|c|c|c|c|c|c|}
\hline Stressor & $\begin{array}{l}\text { All lakes } \\
(\mathrm{n}=72)\end{array}$ & $\begin{array}{l}\text { Lake Superior } \\
\qquad(\mathrm{n}=67)\end{array}$ & $\begin{array}{l}\text { Lake Michigan } \\
\qquad(\mathrm{n}=91)\end{array}$ & $\begin{array}{l}\text { Lake Huron } \\
(\mathrm{n}=104)\end{array}$ & $\begin{array}{c}\text { Lake Erie } \\
(\mathrm{n}=94)\end{array}$ & $\begin{array}{c}\text { Lake Ontario } \\
\quad(n=69)\end{array}$ \\
\hline Invasive mussels & 1 & 3 & 1 & 2 & 1 & 1 \\
\hline Climate, temperature & 2 & 6 & 12 & 8 & 3 & 3 \\
\hline Invasive ballast & 3 & 1 & 2 & 1 & 2 & 2 \\
\hline Toxic metals & 4 & 8 & 8 & 12 & 17 & 16 \\
\hline Climate, water level & 5 & 4 & 7 & 6 & 5 & 5 \\
\hline Invasive lamprey & 6 & 2 & 3 & 5 & 8 & 11 \\
\hline Invasive fish & 7 & 5 & 5 & 3 & 4 & 4 \\
\hline Diporeia decline & 13 & 14 & 4 & 4 & 26 & 7 \\
\hline
\end{tabular}

was introduced to the Great lakes from the Black Sea region. This species preys on mussels and so may play a role in controlling those invasive species. However, round goby are also predators of fish eggs and have been implicated in negative impacts on darters and other native species (Miano 2015).

The list goes on and includes the introduction of numerous aquatic pathogens as well as common carp (Cyprinus carpio) and the occurrence now of Eurasian milfoil (Myriophyllum spicatum), hydrilla (Hydrilla verticillata), and water chestnut (Trapa spicatum) as well as rock snot (Didymosphenia geminate). Clearly, the alteration of the aquatic habitat of the Great lakes and the loss or substantial decline of native species have massively changed this system in a relatively short period. In addition to many other perturbations past, current, and anticipated, climate change and the future of significantly warmer lakes are factors to contemplate.

Smith et al. (2015) ranked the highest-rated environmental stressors in the Laurentian Great Lakes by lake based on expert appraisal (see Table 2). The top-rated stressors included invasive mussels, climate change, invasive ballast, toxic metals, water-level changes, invasive lamprey, invasive fish, and Diporeia decline. Interestingly, cormorants do not appear in the list. Against the backdrop of this dramatically altered aquatic system with associated multitude of expected services, it is clear that cormorants are not considered an important player. In addition, within the context of the myriad changes and stressors that have occurred in this system, it impossible to predict the consequences of any management actions, not the least of which is now cormorant control.

\section{ADAPTIVE RESOURCE MANAGEMENT}

The misguided decision by the Ontario government to persecute cormorants throughout Ontario through public shooting has no scientific basis and is a blatant political response to a vociferous lobby group. Nonetheless, one would assume that such actions would be expected to follow the axioms of adaptive wildlife management. This is a principle that simply says that any management decision needs to be preceded by data collection that can directly inform the consequences of a specific action and to critically monitor key environmental variables related to the action and then to continually reassess the outcome of management and adjust accordingly. I am not aware of any such initiatives by the Ontario government. Moreover, what is the currency that will inform the efficacy of this "control" action? Is it the per capita number of sport fish landed by anglers? Is it some sort of index of happiness of cottage or lakeshore property owners? Regardless, the onus of proof is on the Ontario Ministry of Natural Resources to fully explain how or if adaptive management enters the process. Such management would of course include numbers of cormorants destroyed, their populations before and after the management province wide, but would also include measures of the resource that is supposedly being managed for, e.g., sports fish, ecological integrity of the Great Lakes etc. Adaptive resource management has its problems and relies on relatively simple and stable ecosystems during the period of management but at least it provides a framework for learning the consequences of interventions (Warburton and Norton 2009).

\section{CONCLUSIONS}

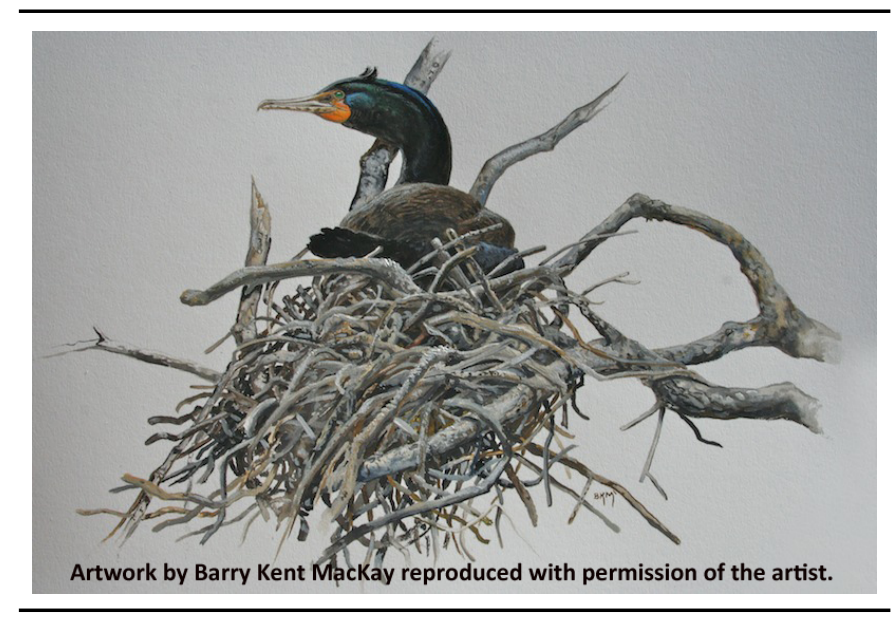

I have spent a career investigating the ecology of a wide array of avian species including the Double-crested Cormorant (Hobson et al. 1989) and have advocated more scientific approaches to the study of cormorant diets (Hobson 2009). Hopefully the massive killing of cormorants in the province will provide a large scientific sample of tissues of birds to be examined for their diet, contaminant loads, etc., but I doubt that will be the case. Most will end up in landfill sites if retrieved. More to the point, we no longer live in a world where we can assume that unlimited human demands on our ecosystems justifies persecution of native species. 
We now live in a world of extinction rates that have never been seen before in the history of the planet. The future of the integrity of the Great Lakes in Ontario is in serious doubt and the record of managers, politicians, and public on both sides of the international border rather lacking. The plight of the Doublecrested Cormorant epitomizes, in my opinion, the conflict in philosophy we currently face. It is abundantly clear that the action to allow public killing of cormorants to 15 per day throughout the province of Ontario has absolutely no place in Canadian society. There can be no doubt that the decision of the new Ontario government to allow public shooting of cormorants is totally misguided, ignorant, and based on little to no scientific evidence. Rather, and as has been demonstrated over and over, the cormorant serves as the convenient scapegoat for all ecological ills of our society. As current co-editor of Avian Conservation and Ecology, I welcome a rebuttal from any group who disagrees and who are actively engaged in the persecution of cormorants in Ontario. However, such a rebuttal would need to conform to the basic principles of scientific evidence and not the familiar dependence on pure perception and opinion common in blogs and social media circles.

Beyond the above, which you can accept or not, there are a few key take-home messages here that I need to emphasize in closing:

1. Designating control of any species to the public is an extremely dangerous policy. We have already seen the disastrous consequences in Wisconsin to allow the public to cull wolves in that state (https://www.theguardian.com/usnews/2021/mar/03/wisconsin-hunters-kill-216-wolves-less-than-60hours-uproar) whereby quotas were exceeded in a few days. Moreover, I would argue that the cormorant culling enthusiasts in the public who, by definition, are untrained in the science of wildlife management and who clearly have ulterior motives, should not be allowed to deliver this management objective. Contrary to current propaganda, the hunting public are generally not "ambassadors" dedicated to restoring ecological integrity to southern Ontario and if they are among the super elite of professional sportsman, what of the vast numbers of individuals out there who are only too happy to use these cormorants for target practice now with official sanction. Moreover, once established, it will be extremely difficult to reverse this trend in public expectations once the public at large believes that cormorants are a problem that need to be solved in this way by government policy.

2. It behooves the government of Ontario to convince the public of Ontario and the rest of Canada that province-wide killing of cormorants by anyone holding a hunting license is a defendable action that follows the principles of adaptive wildlife management. That will require several levels of data on cormorants, fisheries, and the public before, during, and after management objectives are deemed accomplished. To my knowledge, such information is not currently available.

3. There is something about cormorants that elicits hatred among people. It is not clear what this is based on but their appearance and indeed their black coloration begs the question (American White Pelicans are white and do not evoke anywhere near the knee-jerk response despite the fact that they are prime consumers of fish, along with mergansers, grebes, and other less hated species). If this is related only to numbers rather than their "ugly" appearance, then again, some re-evaluation of the role of apparently abundant species in our world requires some serious thought. After all, the Passenger Pigeon (Ectopistes migratorius) and Plains Bison (Bison bison) were all considered overabundant. At some point, the ethics of this entire endeavor must be examined closely and publicly debated (Wires 2014) and sooner rather than later! Barry Kent MacKay (https://www.all-creatures.org/articles/arwhypeople.html) summarized a number of these points as follows:

But there also has to be a place for nature, what's left of it, to be natural, for predator and prey relationships to unfold. There is something sickly sad in not being able to accommodate the Double-crested Cormorant. The world population of the species is less than the number of people in a smaller city, but spread over an entire continent, and yet we say there are too many! We have, when we come to such a place, moved so far from the world of our own origins that I think we have placed ourselves at the risk of believing we are gods, omnipotent rulers independent of the great forces of creation.

Responses to this article can be read online at: https://www.ace-eco.org/issues/responses.php/1949

\section{Acknowledgments:}

I am indebted to Barry Kent MacKay for his splendid generosity for allowing us to reproduce his magnificent and oh so rare illustrations of the Double-crested Cormorant. I also thank Linda Wires for her brave book that provided really the first compendium of the evaluation of how North Americans have treated the Doublecrested Cormorant throughout our history and for documenting so clearly how this species became a "feathered pariah."

\section{LITERATURE CITED}

Christie, W. J. 1974. Changes in the fish species composition of the Great Lakes. Journal of the Fisheries Research Board of Canada 31:827-854. https://doi.org/10.1139/f74-104

Cohen, A. N. 2010. Non-native bacterial and viral pathogens in ballast water: potential for impacts to ESA-listed species under NOAA's jurisdiction. A report prepared for the National Oceanic and Atmospheric Administration, National Marine Fisheries Service, Endangered Species Division, Silver Spring, Maryland, USA. Center for Research on Aquatic Bioinvasions (CRAB), Richmond, California, USA.

Coleman, J. T. H, C. M. Adams, M. Kandel, and M. E. Richmond. 2012. Eating the invaders: the prevalence of round goby (Apollonia melanostomus) in the diet of Double-crested Cormorants on the Niagara River. Waterbirds 35:103-113. https://doi.org/10.1675/063.035.sp111 
Davies-Colley, R. J., and D. G. Smith. 2001. Turbidity, suspended sediment, and water clarity: a review. Journal of the American Water Resources Association 37:1085-1101. https://doi. org/10.1111/j.1752-1688.2001.tb03624.x

Dermott, R. 2001. Sudden disappearance of the Amphipods Diporeia from Eastern Lake Ontario, 1993-1995. Journal of Great Lakes Research 27:423-433. https://doi.org/10.1016/S0380-1330 (01)70657-0

Elrod, J. H., R. O'Gorman, C. P. Schneider, T. H. Eckert, T. Schaner, J. N. Bowlby, and L. P. Schleen. 1995. Lake trout rehabilitation in Lake Ontario. Journal of Great Lakes Research 21:83-107. https://doi.org/10.1016/S0380-1330(95)71085-1

Eshenroder, R. L. 2014. The role of the Champlain canal and Erie canal as putative corridors for colonization of Lake Champlain and Lake Ontario by sea lampreys. Transactions of the American Fisheries Society 143:634-649. https://doi.org/10.1080/00028487.2013 .879818

Fields, S. 2005. Great Lakes resource at risk. Environmental Health Perspectives 113:A164-A173. https://doi.org/10.1289/ ehp.113-a164

Galea, S. 2020. How to hunt cormorants. Ontario Out of Doors, 5 October. [online] URL: https://oodmag.com/how-to-huntcormorants/

Hansen, M. J., C. P. Madenjian, J. W. Slade, T. B. Steeves, P. R. Almeida, and B. R. Quintella 2016. Population ecology of the sea lamprey (Petromyzon marinus) as an invasive species in the Laurentian Great Lakes and an imperiled species in Europe. Reviews in Fish Biology and Fisheries 26:509-535. https://doi. org/10.1007/s11160-016-9440-3

Hobson, K. A. 2009. Trophic interactions between cormorants and fisheries: towards a more quantitative approach using stable isotopes. Waterbirds 32:481-490. https://doi.org/10.1675/063.032.0401

Hobson, K. A., R. W. Knapton, and W. Lysack. 1989. Population, diet and reproductive success of Double-crested Cormorants breeding on Lake Winnipegosis, Manitoba in 1987. Colonial Waterbirds 12:191-197. https://doi.org/10.2307/1521340

Hubbs, C. L., and K. F. Lagler. 1958. Fishes of the Great Lakes region. University of Michigan Press, Ann Arbor, Michigan, USA.

Johnson, J. H., J. F. Farquhar, R. M. Klindt, I. Mazzocchi, and A. Mathers. 2015. From yellow perch to round goby: a review of Double-crested Cormorant diet and fish consumption at three St. Lawrence River colonies, 1999-2013. Journal of Great Lakes Research 41:259-265. https://doi.org/10.1016/j.jglr.2014.12.011

Johnson, J. H., R. M. Ross, and R. D. McCullough. 2002. Little Galloo Island, Lake Ontario: a review of nine years of Doublecrested Cormorant diet and fish consumption information. Journal of Great Lakes Research 28:182-192. https://doi. org/10.1016/S0380-1330(02)70575-3

Johnson, J. H., R. M. Ross, R. D. McCullough, and A. Mathers. 2010. Diet shift of Double-crested Cormorants in eastern Lake Ontario associated with the expansion of the invasive round goby.
Journal of Great Lakes Research 36:242-247. https://doi. org/10.1016/j.jglr.2010.02.013

King, L. E., S. R. de Solla, J. R. Marentette, R. A. Lavoie, T. K. Kyser, L. M. Campbell, M. T. Arts, and J. S. Quinn. 2017. Fatty acids, stable isotopes, and regurgitate reveal diet differences between Lake Ontario and Lake Erie Double-crested Cormorants (Phalacrocorax auritus). Journal of Great Lakes Research 43:132-140. https://doi.org/10.1016/j.jglr.2017.03.004

Magnuson, J. J., K. E. Webster, R. A. Assel, C. J. Bowser, P. J. Dillon, J. G. Eaton, H. E. Evans, E. J. Fee, R. I. Hall, L. R. Mortsch, D. W. Schindler, and F. H. Quinn. 1997. Potential effects of climate changes on aquatic systems: Laurentian Great Lakes and Precambrian Shield region. Hydrological Processes 11:825-871. https://doi.org/10.1002/(SICI)1099-1085(19970630) 11:8<825::AID-HYP509>3.0.CO;2-G

McKenna, Jr, J. E. 2019. The Laurentian Great Lakes: a case study in ecological disturbance and climate change. Fisheries Management and Ecology 26:486-499. https://doi.org/10.1111/ fme. 12317

McLaughlin, R. L., E. R. B. Smyth, T. Castro-Santos, M. L. Jones, M. A. Koops, T. C. Pratt, and L.-A. Vélez-Espino. 2013. Unintended consequences and trade-offs of fish passage. Fish and Fisheries 14:580-604. https://doi.org/10.1111/faf.12003

Miano, A. 2015. Invasive round goby diet patterns and egg predation on broadcast spawning fishes in Upper St. Lawrence River coastal habitats. Thesis. State University of New York, College of Environmental Science and Forestry, Syracuse, New York, USA.

Nico, L., E. Maynard, P. J. Schofield, M. Cannister, J. Larson, A. Fusaro, and M. Neilson. 2021. Cyprinus carpio Linnaeus, 1758. Nonindigenous Aquatic Species Database, U.S. Geological Survey, Gainesville, Florida, USA. [online] URL: https://nas.er. usgs.gov/queries/FactSheet.aspx?SpeciesID=4

Poff, N. L., J. D. Allan, M. B. Bain, J. R. Karr, K. L. Prestegaard, B. D. Richter, R. E. Sparks, and J. C. Stromberg. 1997. The natural flow regime: a paradigm for river conservation and restoration. BioScience 47:769-784. https://doi.org/10.2307/1313099

Reed, J. M., D. Causey, J. Hatch, F. Cooke, and L. Crowder. 2007. Review of the Double-crested Cormorant management plan, 2003: Final report of the AOU Conservation Committee's panel. American Ornithological Society, Chicago, Illinois, USA.

Rucinski, D. K., J. V. DePinto, D. Scavia, and D. Beletsky. 2014. Modeling Lake Erie's hypoxia response to nutrient loads and physical variability. Journal of Great Lakes Research 40:151-161. https://doi.org/10.1016/j.jglr.2014.02.003

Shepard, S. L. 2015. American eel biological species report. U.S. Fish and Wildlife Service, Hadley, Massachusetts, USA.

Siegel-Causey, D. 1997. The problems of being successful: managing interactions between humans and Double-crested Cormorants. Symposium on Double-crested Cormorants: population status and management issues in the Midwest. USDA National Wildlife Research Center Symposia, University of Nebraska Lincoln, USA. [online] URL: https://digitalcommons. unl.edu/nwrccormorants/3/ 
Smith, S. D. P., P. B. McIntyre, B. S. Halpern, R. M. Cooke, A. L. Marino, G. L. Boyer, A. Buchsbaum, G. A. Burton Jr, L. M. Campbell, J. J. H. Ciborowski, et al. 2015. Rating impacts in a multi-stressor world: a quantitative assessment of 50 stressors affecting the Great Lakes. Ecological Applications 25:717-728. https://doi.org/10.1890/14-0366.1

Smith, S. H. 1964. Status of deep-water cisco population of Lake Michigan. Transactions of the American Fisheries Society 93:155-163. https://doi.org/10.1577/1548-8659(1964)93[155:SOTDCP] 2.0.CO;2

Somers, C. M., M. N. Lozer, V. A. Kjoss, and J. S. Quinn. 2003. The invasive round goby (Neogobius melanostomus) in the diet of nestling Double-crested Cormorants (Phalacrocorax auritus) in Hamilton Harbour, Lake Ontario. Journal of Great Lakes Research 29:392-399. https://doi.org/10.1016/S0380-1330(03) 70446-8

Stewart, J. S., S. A. Covert, N. J. Estes, S. M. Westenbroek, D. Krueger, D. J. Wieferich, M. T. Slattery, J. D. Lyons, J. E. McKenna Jr, D. M. Infante, and J. L. Bruce. 2016. FishVis, A regional decision support tool for identifying vulnerabilities of riverine habitat and fishes to climate change in the Great Lakes Region. Scientific Investigations Report 2016-5124. U.S. Geological Survey, Reston, Virginia, USA. https://doi.org/10.3133/ $\operatorname{sir} 20165124$

Trapp, J. L., S. J. Lewis, and D. M. Pence. 1997. Double-crested Cormorant impacts on sport fish: literature review, agency survey, and strategies. Symposium on Double-crested Cormorants: population status and management issues in the Midwest. USDA National Wildlife Research Center Symposia, University of Nebraska Lincoln, USA. [online] URL: https://digitalcommons. unl.edu/nwrccormorants/9/

Van Oosten, J. 1930. The disappearance of the Lake Erie cisco a preliminary report. Transactions of the American Fisheries Society 60:204-214. https://doi.org/10.1577/1548-8659(1930)60 [204:TDOTLE]2.0.CO;2

Warburton, B., and B. G. Norton. 2009. Towards a knowledgebased ethic for lethal control of nuisance wildlife. Journal of Wildlife Management 73:158-164. https://doi.org/10.2193/2007-313

Weidel, B. C., M. G. Walsh, J. P. Holden, and M. J. Connerton, 2017. Lake Ontario Benthic Prey Fish Assessment. Section 12b. New York State Department of Environmental Conservation Annual Lake Ontario Report 2016 to the Great Lakes Fishery Commission's Lake Ontario Committee. March 2017 New York State Department of Environmental Conservation Bureau of Fisheries, Lake Ontario Unit and St. Lawrence River Unit, Albany, New York, USA.
Wires, L. R. 2014.The Double-crested Cormorant: plight of a feathered pariah. Yale University Press, New Haven, Connecticut, USA.

Wires, L. R. 2015. Migratory bird protection, a crack in the armor: the case of the Double-crested Cormorant. Avian Conservation and Ecology 10(1):8. http://dx.doi.org/10.5751/ACE-00761-100108 